\title{
'Christianity Would Not Want a World from which \\ Violence Was Excluded' \\ God, Bataille and Derrida on the Sovereign Logic \\ of Religious Child Killing
}

NICK MANSFIELD

MACQUARIE UNIVERSITY

How do you locate Gilles de Rais (1404-1440) - military figurehead, national hero, serial child-killer, archetype of Bluebeard-in any cultural, historical, political imaginary, in any religious inscape that can make sense of what he was, warrior, homicidal maniac and despicable fool? This is precisely what Georges Bataille attempts in his essay 'The Tragedy of Gilles de Rais', where de Rais finds his place as a remnant of the collapsing world of the feudal seigneur, a world he had outlived, with its military reforms and complex ecclesiastical politics. De Rais' behaviour and fate is tied up in the reconfiguration of a wealth and prestige he had inherited and that he chose to squander, or that he squandered recklessly, mindlessly, without thinking enough to choose. He could do what he did because of the liberties and resources available to the medieval lord: the property, the wealth, the disposability of the plebeian masses ('the little beggars whose throats he cut were worth no more than the horses'), ${ }^{1}$ the stunning irresistibility of the spectacle of aristocratic indulgence ('he gave way without measure to his need to astonish through 
magnificent fairytale expenditures'). ${ }^{2}$ To Bataille, de Rais was a savage child, an animal:

Joined to the god of sovereignty by initiatory rites, the young warriors willingly distinguished themselves in particular by a bestial ferocity; they knew neither rules nor limits. In their ecstatic rage, they were taken for wild animals, for furious bears, for wolves. ${ }^{3}$

The career of Gilles de Rais is caught up then in the rampant libertinage of feudal sovereignty, a sovereignty de Rais risks sovereignly, without regard for the future, for property, for lives, for his social and political place or eternal afterlife. It is in the unfolding of Bataille's account of sovereignty that his story makes sense in its abandonment of sense, its extravagance, its determined, cruel, unnecessary and pointless waste. Yet, Gilles' fate is also wrapped up in the meaning of Christianity or, for Bataille, religion more generally, a religion Gilles embraced by spurning it in his toying with necromancy, but that nevertheless still governed his decisions, even when he was at his most insolent, and to which, in the end, as he approached his execution, he at least pretended to submit. About this religion, Bataille says in a telling aside: 'It may be that Christianity would not want a world from which violence was excluded.'4

What hypocrisy lurks in the will to denounce Christianity's essential violence? A religion of sacrifice yes, but also of authority, repression and damnation cast as love, intimidating in its instituted rhetoric, overawing in its endless recourse to emphatics, an emphatics ironically mirrored in the triumphal, pillaging denunciations of its unreason, its superstition, its hypocrisy yes, it's worth asking: what of Christianity's judgmentalism in spite of itself endures in the corrective speech of those who denounce it? But Bataille would say, Christianity is not the point in itself. The authoritarian violence of Christianity and the judgmentalism of the enthusiasm to denounce it are both phenomena of the larger thing that subsumes them both. Bataille was a renegade from a religion that was too repressive, too limiting, too anti-life, but that in all its overweening force was never enough, in denial of its own constituting excesses, because it was nothing in itself but an exemplar and thus a reduction of a larger human phenomenon, what was most 'generally the condition of [what] each human is', humanity's 'primordial condition, [its] basic condition', the human drive towards sovereignty itself. 5 To 
Bataille, Christianity is not to be evaluated except as an instance of our exposure to the force and lure of sovereignty, that which draws us on to ourselves and the overreaching that we ourselves by nature are.

Religion then emerges as an instantiation of the nexus of violence, subjectivation and truth-dealing that we call sovereignty. The aim of this article is to situate Gilles de Rais in Bataille's account of sovereignty in order to reveal not the calumny of sovereignty, but its resistance to the logic of ideality and preference to which it is usually referred, traditionally positively, now negatively, to show sovereignty as Bataille wanted to see it, as he saw transgression, not as something to advocate but something in us larger than will, purpose or comprehension. Sovereignty exposes us to the abyss as authority, an authority that offers us a violent and thus meaningful, commanding subjectivity that lures us on but that we cannot have. Then, through de Rais I want to read Derrida's account of Abraham's nearsacrifice of Isaac in order to see God as a figure of this violence that we cannot have, and through God, other avatars of a grounding sovereign violence, justice and democracy.

'Sovereignty comes first', Bataille writes. ${ }^{6}$ In Bataille's account, sovereignty is the primordial, fundamental human quality. It embodies the human relationship with the world of the physical, specifically the animal world which the human alienates by a process of objectification:

It is man in general, whose existence partakes necessarily of the subject, who sets himself in general against things, and for example against animals, which he kills and eats. Affirming himself, in spite of everything, as a subject, he is sovereign with respect to the thing an animal is. ${ }^{7}$

The human constructs itself by dominating the animal world which remains locked in thingness. In this way, the human frees itself from being a thing itself, ceasing to be an object and becoming a subject. Subjectivity is not simply identified with humanity, nor is it something humanity either releases or expresses. Instead, it is something that humanity can rise to-can partake of-by way of its objectification of the world of things, exemplified in the animal that the human kills and eats. Subjectivity is the cardinal achievement of human self-affirmation. 
Yet this process of subjectification divides the human from itself as much as it divides the human from the animal. The social world forms around this divide just as readily. The 'traditional sovereign' may exemplify what is most authentically human, but it also institutes a social hierarchy that separates the aristocratic from the plebeian:

In traditional sovereignty, one man in principle has the benefit of the subject, but this doesn't just mean that the masses labour while he consumes a large share of the products of their labour: it also presupposes that the masses see the sovereign as the subject of whom they are the object. 8

Sovereign ascendancy does not simply rest then on an unequal distribution of labour and property, or even simply of prerogative. The sovereign is established in its social ascendancy by assuming subjectivity and turning the socially inferior into objects. Yet those humans at the bottom of the social scale do not become like animals. They recognise subjectivity as the thing that orders their lives, even when they do not 'partake' of it in the same way as the sovereign. Subjectivity is both what they serve and the thing to which they aspire. In recognising the sovereign, the 'individual of the multitude' does not simply abase himself. He 'recognises himself in the sovereign'. ${ }^{9}$ The sovereign becomes not only the apex of social aspiration but the very identity of 'inner experience', 10 and the possibility of sociality itself. The sovereign is the intermediary between individuals, the thing that binds humans together in communication and thus community.

The sovereign then governs the social by exemplifying individuality. This individuality is not autochthonous, but something larger than the human of which the human partakes. The sovereign figure channels the subjectivity that remains always in excess of it. 'Traditional' subjectivity may make the mistake of vesting sovereignty in the human individuals who merely figure it. Sovereignty is not thus a person but the idea of itself that the human derives from its overcoming of the object-world, and which it then institutes as the logic of the social.

The social and the sovereign then must be in an intimate yet still disjunctive relationship. The social is organised around the idea of the sovereign, an idea it sees actually literally incarnated in the dominant social individual, whom the multitude use as an emblem of their aspiration and the engine of interrelationship. Yet this 
figure of the sovereign is anti-social. It guarantees its own social ascendancy by savaging the social. Sovereignty is the 'negation of prohibition', the confirmation of the social by way of the rupture of all rule. ${ }^{11}$ The sovereign is the lodestone of the social but it transcends it as well. It may profit from the world of labour and utility, which indeed makes its extravagances possible, but which it spurns in its radical commitment to the now, regardless of expense and consequences. It is the possibility of a life opening up 'beyond utility' and 'without limit'.12 This denial of all limits reaches, of course, to violence. Bataille writes:

This relative alienation, and not slavery, defines from the first the sovereign man who, insofar as his sovereignty is genuine, alone enjoys a nonalienated condition. He alone has a condition comparable to that of the wild animal, and he is sacred, being above things, which he possesses and makes use of. But what is within him has, relative to things, a destructive violence, for example the violence of death. ${ }^{13}$

It is in its enthusiasm for death that the sovereign's absolute contempt for limits and inhibition most clearly manifests itself. Death cannot be assimilated into the utilitarian logic of the workaday world. ${ }^{14}$ It defies the logic of individuality that the sovereign would have seemed to ensure. The sovereign thus is the archetype of human individuality in its freedom from the constraint of individuality in an openness on death. This freedom manifests itself not simply in risk and courage, but in violence and killing. The sovereign may underwrite the social but only by exposing the social to that which transcends and defies its most fundamental rule, the prohibition against killing:

sovereignty is essentially the refusal to accept the limits that the fear of death would have us respect in order to ensure, in a general way, the laboriously peaceful life of individuals. Killing is not the only way to regain sovereign life, but sovereignty is always linked to a denial of the sentiments that death controls. Sovereignty requires the strength to violate the prohibition against killing, although it's true this will be under the conditions that customs define. 15

The human is thus exemplified in the sovereign which is a figure of the murderous violence that transcends and threatens the human, a violence in turn not answerable 
to the human. The multitude's hope of human individuality is grounded then in a murderous violence directed against it and of which it cannot partake.

Sovereignty's investment in death is not merely social or political, however. Its spurning of the real world of utility and teleology brings it by way of freedom to the nothingness that transcends all purpose and meaning. Bataille writes of the exercise of sovereignty as the 'miraculous moment when anticipation dissolves into NOTHING, detaching us from the ground on which we were grovelling, in the concatenation of useful activity'.16 Indeed, sovereignty itself becomes nothing: 'The thought that comes to a halt in the face of what is sovereign rightfully pursues its operation to the point where its object dissolves into NOTHING, because, ceasing to be useful, or subordinate, it becomes sovereign in ceasing to be'. ${ }^{17}$ In exceeding the world of utility and purpose, the sovereign extinguishes itself as a real thing, defying ontology as the definitive administration of the limit. This excess is the miracle of the sacred to Bataille. The power of which the sovereign partakes is the extraontological prerogative of ultimate subjectivity, the divine.18 Whatever dimension of human individuality or subjectivity that is available to me is the slippage into this world of the sacred nothingness that makes individuality possible but that is always larger than it, and that defies it, by revealing an otherness to which it aspires but with which it can never be simply identified: 'What is sacred ... is for example myself, or something that, presenting itself from the outside, partakes of me, something that, being me, is nevertheless not me (it is not me in the sense in which I take myself for an individual, a thing): it may be a god or a dead person, because, where it is concerned, to be or not to be is never a question that can be seriously (or logically) raised'. The sign of this defiance of the real world is death, which is 'the appearance that the whole natural given assumes insofar as it cannot be assimilated, cannot be incorporated into the coherent and clear world'.19 Death is the ultimate luxury for Bataille, the thing to which individuality aspires as its apotheosis: 'this miracle to which the whole of humanity aspires is manifested among us in the form of beauty, of wealth-in the form, moreover, of violence, of funereal and sacred sadness, in the form of glory'.20 
What can be made of Gilles de Rais: warrior-general-hero who fought beside Joan of Arc, yet was the most degraded and disgusting child-killer? During his trial the following is said to be the material of de Rais' confession, that:

He took and had others take so many children that he could not determine with certitude the number whom he'd killed and caused to be killed, with whom he committed the vice and sin of sodomy; and he said and he confessed that he had ejaculated spermatic seed in the most culpable fashion on the bellies of the said children, as much after their deaths as during it; on which children sometimes he and sometimes some of his accomplices ... inflicted various types and manners of torment; sometimes they severed the head from the body with dirks, daggers, and knives, sometimes they struck them violently on the head with a cudgel or other blunt instruments, sometimes they suspended them with cords from a peg or small hook in his room, and strangled them; and when they were languishing, he committed the sodomitic vice on them in the aforesaid manner. Which children dead, he embraced them, and he gave way to contemplating those who had the most beautiful heads and members, and he had their bodies cruelly opened up and delighted at the sight of their internal organs; and very often, when the said children were dying, he sat on their bellies and delighted in watching them die thus and with the aforesaid Corillaut and Henriet he laughed at them, after which he had the children burned and their cadavers turned to ashes. ${ }^{21}$

How many children did he kill in this way? Hundreds perhaps. So many 'such that the exact number cannot be certified'.22 The Western fear of the monstrous lord in the forbidding castle into which little children disappear never to return is said to spring from the story of Gilles de Rais.

Gilles de Rais is a figure of 'sovereign monstrosity' to Bataille. ${ }^{23}$ Why? As we have seen in the outline of Bataille's account above, traditional sovereignty is first identified as a phenomenon of social ascendancy: 'he is not just any man in the world, but a noble ... the nobility of Gilles de Rais is the distinguishing mark of the monster' ${ }^{24}$ The fact that de Rais did not act alone, but enlisted a network of servants and lackeys to lure children into his hands showed that his crimes did not seem automatically to repulse people, because they were after all simply 'to do with a 
great lord and miserable children'. ${ }^{25}$ Nobles had, according to Bataille, 'every chance to take almost unmerciful advantage of young serfs' ${ }^{26}$

This social ascendancy not only allowed the spectacular indulgence of the nobility but it required it and was defined by it. The point of the feudal economy was to licence the wasteful splendour of the aristocracy:

Men, on the whole, produce; they produce every kind of good. But in 15thcentury society, these goods were destined for the privileged class, for those who among themselves can devour each other, but to whom the masses are subordinate. For the mass of men it is necessary to work so the privileged class can play, even if they also sometimes play at devouring themselves to their ruin. ${ }^{27}$

That hundreds of children would be at the disposal of a noble lord, who chose to destroy them, simply for his own pleasure, is not in contradiction with such a noble system in which unproductive squandering of foods, goods and lives makes sense. It is true that de Rais was tried and executed for these crimes, but he only came to the critical attention of authorities because of some ill-judged threatening political behaviour, in which he stormed a church in order to hold hostage the brother of a political rival. These offences against political enemies in an act committed in a church building and therefore taken by the church as blasphemy, was what exposed him first to trial. That he could no longer get away with this style of political intimidation may perhaps also signify that his way of being was coming to an end. Even in the way some of his crimes are reported in the official documents of his case, it seems that the sadistic murder of hundreds of unprotected little children is taken to be less outrageous than offences committed against political enemies and the church. Bataille wonders if he would have got away with the murders if he had not blundered so badly politically.

The social reality which allowed Gilles de Rais to commit his crimes exemplifies the ascendancy that Bataille identifies with 'traditional sovereignty'. Yet it also conforms to the fuller account of sovereignty as the exposure of the human to violence, chaos and meaninglessness, and thus religiosity. ${ }^{28}$ Of de Rais' 'nobility of an ardour respecting nothing', Bataille writes:

In Gilles' eyes, mankind was no more than an element of voluptuous turmoil; this element was entirely at his sovereign disposal, having no 
other meaning than a possibility for more violent pleasure, and he did not stop losing himself in that pleasure. ${ }^{29}$

This sovereign exposure to that which exceeds sense and meaning in a violent pleasure in killing, makes de Rais' monstrosity sacred to Bataille, because it is in the violent bringing of death into the world that the sacred becomes visible. De Rais is a religious figure to Bataille, and indeed de Rais found religious ceremonies 'intoxicating'.30 As we will see, even his murders were wrapped up in a comical religious experimentation, a pathetic and gullible necromancy in which he was fooled by retainers into a hopeless conjuring of evil spirits. Bataille writes of de Rais: 'he doubtless developed a superstitious image of himself, as if he were of another nature, a kind of supernatural being attended by God and by the Devil ... he had a feeling of belonging to the sacred world'. ${ }^{31}$ To Bataille, de Rais' career belongs then to Christianity, a religion which cannot live without sacred violence, that 'is even fundamentally the pressing demand for crime',32 because it only makes sense in providing the strength to endure violence:

Gilles de Rais' contradictions ultimately summarise the Christian situation, and we should not be astonished at the comedy of being devoted to the Devil, wanting to cut the throats of as many children as he could, yet expecting the salvation of his eternal soul.33

Gilles is an archetypal figure of Bataillean sovereignty therefore, of its social ascendancy, its exposure to violence, chaos and meaninglessness and its immersion in the cruelty of a limitless death as a way of encountering the sacred. Yet, even in his sovereignty, not only is de Rais despicable and repulsive, but also gullible, foolish and laughable. We should not be seduced by the charisma of sovereignty, or by the enthusiasms of transgression more generally. These are not things simply to admire or to advocate in Bataille. To advocate the shattering of values is impossible without turning shattering into a value and thus repeating the servility it is supposed to overcome. Advocacy would also reduce sovereignty to a realisable historical project, something Bataille explicitly excludes in The Accursed Share, where he writes: 'sovereignty cannot be understood as a form history would realise'. ${ }^{34}$ De Rais may be sovereign in his abject freedom, yet he is not a hero. He is, even in his cruelty, a ridiculous figure, a warrior superannuated by the military reforms of Charles VIII, which made his kind useless. His arrest shows that his style of behaviour was 
becoming anachronistic. He represents no ideal or hope. Even as sovereign in his orgiastic and sacred violence, he is a fool and a failure. What does his sovereign failure tell us about sovereignty, especially in its relation to religion, and beyond religion to politics?

God is a killer too, of course, and God's battles with evil cause many deaths. It is not Gilles de Rais that introduces death as the meaning of religious subjectivity, whether that subjectivity be the eternal life available to the redeemed fraction of humanity passing to the right hand of God, or our impertinent indulgence in luxurious necromancies. Yet, killing is God's right, a right that doesn't belong to humanity, and that de Rais usurps. I now want to compare the case of Gilles de Rais with that of the patriarch Abraham, especially as mediated through the reading provided by Jacques Derrida in The Gift of Death. The case of Gilles de Rais exemplifies the ambiguities of the human in relation to the sovereignty to which it aspires and which defines it. As we have seen, the sovereign is an elusive and illusory figure who seems to incarnate human possibility. In transcending the practical obligations of the diurnal world of purpose and work, the sovereign is the asymptote of human aspiration, the license and measure of human subjectivity, the lodestone of human sociality in its very defiance of the obligations of the social, the hero of human life and freedom in its embrace of death and oppression. It is in his determination to act out this sovereignty that Gilles de Rais becomes so monstrous. Yet the riddle of Gilles de Rais is that what makes him so effectively incarnate the heroism of sovereignty also makes him a ridiculous failure. His assumption of sovereignty diminishes him, and does not encourage us to exempt him from culpability for despicable crimes. Why does his smashing of the limits of logic, accountability and practical social survival, his self-elevation to sovereignty, his human attempt to make sovereignty livable, still make him so contemptible? It is these questions that the comparison with Abraham helps to elucidate.

God directs Abraham to kill his son, Isaac. Abraham sets out on the journey as instructed, without questioning God's will, even though it seems to contradict God's own pronouncement on the birth of his child that it would be through him that Abraham would bless all the generations of the world. There is more at stake here 
than mere obedience or even faith. God is a figure of Bataillean sovereignty, the superhuman figuration that models, causes and guarantees subjectivity, from a position outside conventional reason and meaning. This arises because in obeying God's will, Abraham is plunged into an aporia. He must both maintain his love for Isaac as his father, while also submitting to the absolute-ness of God's will. For his obedience to God to matter, he must love Isaac as intensely as ever, while at the same time honouring God's rule by killing him. His commitment to the domestic, economic logic of familial obligation must persist even at the same time as he commits most strongly to God's requirement that this familial duty be sacrificed. The sacrifice would be trivial or meaningless otherwise. In order to conform to the ethical requirement to obey God, he must fully feel his ethical obligation to protect his son, while being determined to kill him. Derrida writes:

The two duties must contradict one another, one must subordinate ... the other. Abraham must assume absolute responsibility for sacrificing his son by sacrificing ethics, but in order for there to be a sacrifice, the ethical must retain all its value; the love for his son must remain intact, and the order of human duty must continue to insist on its rights. 35

Abraham must thus fully respect the ethics God requires he destroy in order to serve another ethic. Abraham must be completely treacherous in order to be completely faithful. This obligation requires of him a conformity to rule and a precarious decisionism, a rule that marks him out as typical, yet his is a typicality simultaneous with a punctual singularity, a decision to act, a decision that must be taken not by anyone anywhere, but by him, and now. This contradiction installs in him a unique interiority that can be neither shared nor even readily articulated, in Kierkegaard's terms, a secrecy.

This secrecy is his conformity to God's insane, unmotivated a-logic of the gift, in this case, the 'gift of death.' The domestic logic of known and reciprocal responsibility is sundered by God's asymmetrical, unaccountable command to sacrifice Isaac, against all ethics, even against God's own previous pronouncements. Isaac is to be killed now before he can be the father of generations God has said he will be. In God's logic he will become the father of peoples yet be killed as a child. The mundane logic of duty and order, or fatherly care and responsibility is shattered by the very father, God, who would have seemed to command it. He takes away from 
Abraham the reward for his piety, virtue, loyalty and patience, the son born to him late in life as a recompense for all he has endured and seen. Abraham must conform to the chaotic, aporetic logic of God's gift, by making in turn a gift to God that he cannot hope to understand or explain. Yet, the absolute irony is that God restores Isaac to him, orders him at the very last moment to hold back from killing his son, offering a substitute in his stead. This is the double insanity of God's logic, not only must the obscure law of the gift overcome the economic logic of obligation and return which Abraham had been living in his piety, but even by way of the aporia of the gift, Abraham will still be rewarded: another economy emerges, an even more insane Godly economy in which not only must Abraham give up everything he holds most dear, but one in which in the end, he will be allowed to keep it, a logic in which he both sacrifices and does not lose, what Derrida calls 'the sacrifice of sacrifice.'

Yet what has been at stake is not only ethics, but subjectivity. Abraham's commitment to God's self-contradictory will, his immersion in secrecy, provides the shape of his subjectivity by installing a version of God-ness within him. Derrida writes of the process of folding inwards that installs the secret world of conscience that God has animated through this drama: 'God is in me, he is the absolute "me" or "self", he is that structure of invisible interiority that is called ... subjectivity.'36 Abraham commits to this subjectivity, even though it is built on what Kierkegaard identified as absurdity. Derrida sees it as an aporia, 'the chaos of the undecidable'.

Human subjectivity only arises then as a version of God's subjectivity installed within. God is the absolute self, and by taking on his insane logic in the madness of the decision to sacrifice Isaac, to sacrifice fatherly obligation, domestic love, to sacrifice everything, Abraham can act as a self acts, can become the aporia as event, the obscure secret thing in action. Yet the relationship between God and Abraham is not symmetrical. Abraham may become like God, but is not God himself. God commands, then changes his command. Abraham obeys. He doesn't make the decision to kill or not to kill. Abraham's decision is whether to obey God or not, not whether to kill or not. God is the killer. It is God who scorns the logic of the domestic and familial, it is God who is indifferent to love. Abraham preserves his commitment to all these things. His only decision is whether to subordinate them to something higher. God inhabits the world of rupture and violation. It is God who exposes Abraham to absolute risk, by bringing into the world a violence that Abraham is 
incapable of understanding, a violence constructed not on Abraham's terms, but on God's, a violence that smashes all the limits of the Law. Abraham can make sense of the logic of obedience, but God violates obedience to the law by calling for an act of obedience to his own authority, an act of obedience which he then violates by interrupting it. God's ever-renewing violence is not itself comprehensible. God's violence is limitless and in itself beyond meaning. It signifies the absolute alienation of divinity in its limitless terror from the logic of the human. God may install subjectivity within the human as a version of what he may be himself, but he always exceeds and confutes this subjectivity, going beyond it into a dizzying limitlessness. There is no end to the violence he can do to the human. As Derrida says in 'Force of Law: The Mystical Foundations of Authority': 'God is the name of this pure violence.' 37

Abraham's subjectivity forms in relation to a divine violence which is not his. He cannot do anything other than enact God's violence, but from his point of view, the violence itself is not the issue. Or rather, it is not his issue. It is not his role to evaluate the violence, and he does not. His enactment of God's violence does not become his own violence, because what motivates him is not violence but obedience. He is not God. He does not kill the child. This is what distinguishes him from Gilles de Rais. The right to kill the child does not belong to Abraham. It is God's right. Abraham only has the right to obey. His exposure to God-ness elevates and enriches him in that it constructs within him the dynamic of the secret that is his subjectivity, but he does not become the pure violence that is God. His subjectivity depends not only on his being a version of God-ness, but also on how much he is not God. Gilles takes on the absolute violence of sovereignty, but in so doing acts like he is sovereignty, that his power and violence are limitless. The absolute violence of sovereignty enlarges human subjectivity, but only in that subjectivity does not lose its difference from that violence. Human subjectivity becomes possible only in its orientation to that which exceeds and transgresses it, that calls it on towards what is larger, more disruptive, that violates human meaning and destroys what makes us secure. It is only in exposure to this danger that the subject can live the dynamic of self-overcoming that we call life. If the human loses the difference between itself and that which exceeds it, then it becomes its own excess. Yet this is impossible because something cannot become its own excess without cancelling excess out. Gilles takes 
absolute violence on himself, and thus loses his difference from that which constitutes his subjectivity by exceeding him. In short, he ceases to be a subject and becomes ridiculous, of no consequence or significance. Nothing can defend or justify him. He passes beyond the exposure to meaninglessness that extends subjectivity and himself becomes meaningless. In becoming sovereignty, he loses the relationship to sovereignty that would have made of him some mode of exemplary subjectivity. He kills the children and becomes despicable, monstrous, beyond human.

It is here that we make sense of Bataille's statement about Christian violence. For all their posturing about love and peace, the religions of the book require the violence of God as the thing from which the human must separate itself. This violence arises as the absolute possibility of human failure, but the human failure to distinguish itself from violence, by making the mistake of thinking itself God. The Christian condemnation of violence as evil is not the pronouncement of the absolute separation of God's ethics from violence, but the arrogation of violence to God himself. The worst evil a human subject could do is to lose the sense of distance between itself and the violence God is. Then the subjectivity that this violence makes possible becomes anchorless, free floating and un-ruled. Only God has this right. The mistake of Gilles de Rais was not to imitate sovereignty but to act as if he had become it. Thus he became nothing. Abraham lives out a subjectivity in which he both is God (in the instantiation of his subjectivity) and not God (in that Godness moves within him without him actually becoming God). It is this aporetic Godly nonGodness that allows him to live on as loving father by withholding his hand. Gilles loses the difference between himself and his sovereignty. He forgets that even in acting sovereignly that he has not become sovereignty itself. Subjectivity sunders.

We are talking about the killing of children, perpetrated either by God or by a vacuous non-self, so we are not simply making a theological point nor using violence as a metaphor. Suspended timelessly in the twilight world between fairy tale and nightmare, the terror of the children Gilles de Rais killed inhabits Western culture as the epitome of the unthinkable still widely thought. This unthinkable cannot be erased from our broader philosophical consciousness either. To Bataille, God was 
simply an attempt to literalise or personalise that larger phenomenon of the unreachable, undefinable, unlivable thing that oriented human subjectivity, sovereignty. Sovereignty is not merely a rhetorical abstraction of a religious consciousness. For Bataille, it is clearly the other way round. God is the name we use to protect ourselves from the sovereignty that is forever our horizon. This definition of sovereignty echoes in Derrida's account of the story of Abraham, but also in his discussions of more political concepts, especially justice and democracy.

To Derrida, law is instituted in relation to a justice that is always larger than it. Law attempts to institute justice in the world, and gains whatever authority it has by its evocation of justice and its perpetual attempt to enact it. Yet the law will never be just enough. It will always be subject to reform, improvement, refinement, to being more effective, more far-reaching, a purer enunciation and instantiation of justice. In this way, justice always requires more of law than it is capable of giving. It can always challenge, harry or deconstruct the law. It thus always threatens, undermines and violates the law. The law arises only in this perpetual violation of itself in the name of pursuing justice. Justice arises as the law's violation of itself in its endless quest for improvement. Law then must act out justice but if it became justice, it would become only the violence that it does to itself. For law to identify with the absoluteness of justice, it would thus become pure violence, unaccountable, unlicensed, massacring.

The same risk arises with democracy. To Derrida, democracy as an instituted political system is always oriented towards what he calls democracy-to-come, the horizon of ever-extending equity, freedom and openness that gives democratic institutions their orientation, justification and meaning. Democracy-to-come is not an ideal against which we measure our present arrangements, nor is it a goal that we can one day expect to realise. It is the impulse to reform and improve always and forever our democratic values and practices. We are open to the ever-expanding possibilities of democracy-to-come because it is itself open-ness. Yet in its will to convert all, to saturate the human world, to re-model all societies, the orientation of democratic actors towards an infinite democracy-to-come threatens to become another unaccountable violence. A loss of the constituting aporia that puts democracy in relation to the democracy-to-come that gives it meaning but that it 
must not become, that it must not mistake for something realisable, risks a violence that would persist beyond the world of what is knowable and measurable.

We are blessed with the misfortune of aporia. Sovereignty and its hypostasesGod, justice, democracy-are the names of a limitless violence from which we are commanded to exempt ourselves, even as we are sometimes commanded to execute that violence. In this complex arrangement, God both demands and forbids violence in one and the same act, requiring violence while also becoming a figuration of the demand for absolute and eternal peace. The same can be said of justice and democracy. They require a violence that they forbid. This is the meaning of Derridean doubleness. For Derrida, aporia is not an elegant ambiguity, nor is it the pathos of ambivalence in which a reluctant, reflective hero is poised between incommensurable options, a hero who is to be enlarged and intensified by having to make the forward move into decision, ever reluctantly in an affectation of worldly wisdom. In doubleness, the commitment to peace cannot be other than the confirmation of the meaning of violence. In this way, God's love requires violence and would be nothing without it.

How many children did Gilles de Rais kill? A hundred? Two hundred? A thousand? Nobody knows. His violence knew no limit because he mistook the sovereign logic that gives rise to subjectivity for something that he could actually be. In this way, his violence knew no limit but he also became nothing. How many people has God killed? Or justice? Or democracy? Terrifyingly, these hundreds of thousands of deaths matter to us less than the murders perpetrated by a single mad killer. They have less weight because they were done in the name of things we still believe give us life and enlarge us. These gods kill in us. That a person, a nation, a culture, a West might think of itself as democracy means it bears its God into the desert of a limitless possibility of ever extending violence whose primary function is to enrich a subjectivity by going beyond it in a promise to others that is never kept. That God would be the name of this abuse reveals not simply the religious logic of political enthusiasm, but also the sovereign abyss which these eminently deconstructible terms (God, religion, politics) attempt to simultaneously articulate and conceal. The sovereign will to enlarge, to extend, to enlighten, to free, both governs and threatens. This is the aporia of the transgression that endlessly suggests a violence we can neither approve nor do without, the transgression 
captured in the cross's offer of redemption in luring into the world-in order to kill his own child—God the sovereign killer.

Nick Mansfield is Dean, Higher Degree Research and Professor of Critical and Cultural Studies at Macquarie University in Sydney. His most recent books include Theorizing War: From Hobbes to Badiou (2008) and The God Who Deconstructs Himself: Subjectivity and Sovereignty Between Freud, Bataille and Derrida (2010). He is one of the general editors of the journal Derrida Today (Edinburgh UP). This article is part of a book-length project on sovereignty and violence.

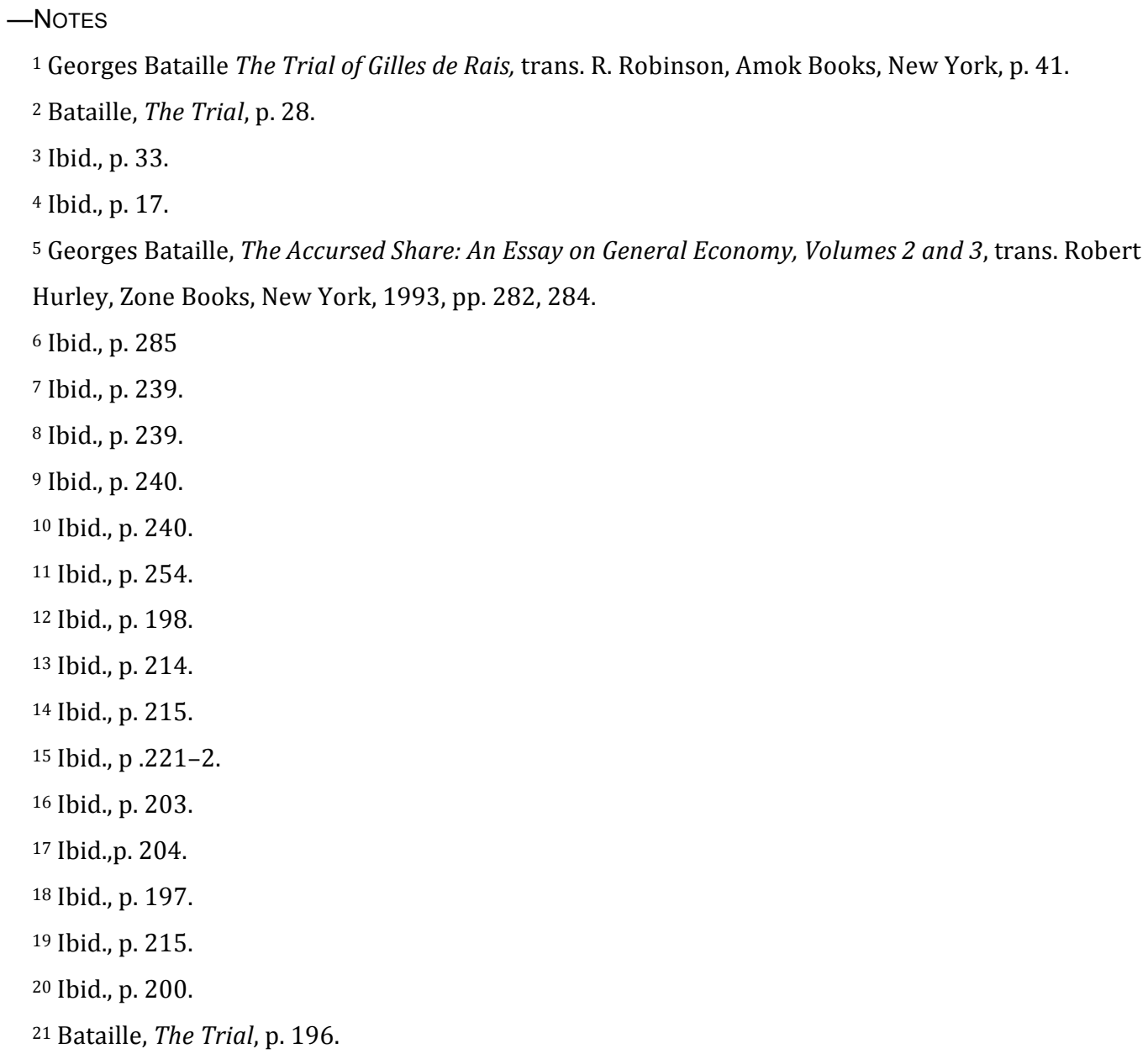


22 Ibid., p. 250.

23 Ibid., p. 20.

24 Ibid., p. 41.

25 Ibid., p. 102.

26 Ibid., p. 34.

27 Ibid., p. 42.

28 Ibid., p. 21.

${ }^{29}$ Ibid., pp. 41, 40.

30 Ibid., p. 89.

31 Ibid., p. 16.

32 Ibid.

33 Ibid., p. 17.

${ }^{34}$ Bataille, Accursed Share, p. 302.

35 Jacques Derrida, The Gift of Death, trans. David Wills, University of Chicago Press, Chicago, 1995, p. 66.

36 Ibid., p. 109.

${ }^{37}$ Jacques Derrida, 'Force of Law: The Mystical Foundation of Authority' in Acts of Religion, ed. Gil Anidjar, Routledge, New York, 293. 